ORIGINAL ARTICLE-

Volume 15 Issue 22020

DOI: 10.21315/aos2020.15.2.421

ARTICLE INFO

Submitted: $16 / 11 / 2019$

Accepted: $14 / 11 / 2020$

Online: 24/12/2020

\section{Demographics and Clinical Profile of Orofacial Cleft in International Islamic University Malaysia from 2009 until 2018}

\author{
Noraini Abu Bakara*, Sakinah Azman ${ }^{\text {b }}$, Syahirah Syazwani Jaffar ${ }^{\text {, }}$ \\ Nor Asilah Harunc, Khairani Idah Mokhtar ${ }^{\mathrm{d}}$ \\ ${ }^{a}$ Department of Orthodontics, Kulliyyah of Dentistry, International \\ Islamic University Malaysia, 25200 Kuantan, Pahang, Malaysia \\ ${ }^{b}$ Kulliyyah of Dentistry, International Islamic University Malaysia, \\ 25200 Kuantan, Pahang, Malaysia
}

'Department of Paediatric Dentistry and Dental Public Health, Kulliyyah of Dentistry, International Islamic University Malaysia, 25200 Kuantan, Pahang, Malaysia

${ }^{d}$ Department of Fundamental Dental $\mathcal{E}$ Medical Sciences, Kulliyyah of Dentistry, International Islamic University Malaysia, 25200 Kuantan, Pahang, Malaysia

${ }^{\star}$ Corresponding author: nor_aini@iium.edu.my

To cite this article: Abu Bakar N, Azman S, Jaffar SS, Harun NA, Mokhtar KI (2020). Demographics and clinical profile of orofacial cleft in International Islamic University Malaysia from 2009 until 2018. Arch Orofac Sci, 15(2): 97-107. https://doi.org/10.21315/aos2020.15.2.421

To link to this article: https://doi.org/10.21315/aos2020.15.2.421

\begin{abstract}
Orofacial clefts (OFC) are the most common craniofacial anomalies. There is no published data regarding the demographic of OFC cases seen in International Islamic University Malaysia (IIUM), since the establishment of the IIUM Multi-Disciplinary Cleft Team (IIUM-MDCT). The present study aimed to build a database on demographic profile of OFC cases seen in IIUM from 2009 until 2018. Data from all registered OFC cases were obtained from the medical records. Birth prevalence was tabulated against the population statistics for the period, obtained from the Department of Statistics Malaysia. A total of 20 cases were seen over the period of nine years. The registry recorded about $60 \%$ of females and $40 \%$ of males. Age distribution was $40 \%$ below the age of 10 years old, $40 \%$ between 11 to 20 years old and $20 \%$ of 21 years old and above. As for race, $90 \%$ were Malay, $5 \%$ were Chinese and Indian, respectively. Majority of patients (75\%) were from Kuantan, $10 \%$ from Kemaman and 5\% from Pekan, Kuala Terengganu and Kota Bharu, respectively. The most common OFC was cleft lip and palate $(80 \%)$, followed by cleft palate $(15 \%)$ and facial cleft $(5 \%)$. The LAHSHAL classification was recorded with $75 \%$ of cases were unilateral, of which $73 \%$ affecting the left side. Other health anomalies were recognised in $45 \%$ of cases and $20 \%$ of them has family history of cleft. The present study could provide a baseline information on the status of OFC patients seen by IIUM-MDCT.
\end{abstract}

Keywords: Cleft classification; cleft multidisciplinary management; demographics; orofacial clefts 


\section{INTRODUCTION}

Cleft lip with or without cleft palate and cleft palate only are common congenital malformations (accounting for 65\%) of head and neck anomalies (LaRossa, 1997). The term cleft lip and palate inadequately describe the potential complexities of the deformity, which may involve nose, lips, alveolus or palate. Consequently, breathing, appearance, dentition, dental occlusion facial growth, speech and hearing can all be affected which would also lead to psychosocial implications (Dvivedi and Dvivedi, 2012).

The exact cause of oral cleft is unknown; in most cases, $15 \%$ of the total number of cases of oral clefts are syndromic (Ali Shah et al., 2015). Genetic plays important role in the non-syndromic oral clefts, however the mode of inheritance is not fully understood. It is likely that the majority of environmental factors act in conjunction with genetic factors and other environmental exposure (Fraser, 1976). Among the environmental factors that has shown to increase risk of oral clefts are nutritional deficiencies, drug consumption (Källén, 2003), radiation or smoking during pregnancy (Källén, 1997).

A number of studies have been conducted on the incidence rate of oral clefts per 1,000 live births. Incidence of 0.5 to 2 per 1,000 live births has been reported depending on the population being studied. In Southeast Asia, the incidence of oral clefts is 1.52 per 1,000 live births in Manila, Philippines (Vanderas, 1987), 2.07 per 1,000 live births in Thailand (Jaruratanasirikul et al., 2008), and 2.07 per 1,000 live births in Singapore (Yi et al., 1999).

In Malaysia, the incidence of oral clefts is 1.24 per 1,000 live births (Thong et al., 2005). The Chinese babies had the highest incidence (1.9 per 1,000 deliveries) while the Malays had the lowest (0.98 per 1,000 deliveries). The most common type was unilateral cleft of the primary and secondary palates. Cleft of the secondary palate was most common among the Indian babies (Boo and Arshad, 1990).
In International Islamic University Malaysia (IIUM), cleft cases had been seen and handled individually since 2009. Such management without the holistic multidisciplinary input had proven to be ineffective; hence in 2016, efforts were made by the Kulliyyah of Dentistry to establish the IIUM Multi-Disciplinary Cleft Team (IIUM-MDCT) to treat OFC cases more effectively. The present study would create a database of the demographics of orofacial cleft seen from 2009 up to October 2018 and help the team in the planning and management of the patients. The main aim of the present study was to determine the demographic profile of orofacial cleft cases that were presented at IIUM over the period of nine years (2009-2018).

\section{MATERIALS AND METHODS}

This was a retrospective study that reviewed all data from year 2009 until October 2018. After getting consent and ethical approval from IIUM Research Ethical Committee (IREC IIUM/504/14/11/3/ 2017-072), the data of total sample, which comprised 20 patients with orofacial clefts presented from year 2009 until October 2018 were collected. Data extraction form was used to collect data from patients' folders. The data included were age and sex, cleft types, associated health problems, family history of clefts, socioeconomic status, history of treatment received and current treatment status. Additional data extraction was also done through direct phone calls to parents or guardian to ensure accuracy and completeness of the data extracted. All data collected were entered and subsequently analysed by using the IBM SPSS Statistics 23 (IBM, USA). Chi-square test was performed to calculate the significant association between demographic factors (gender, race and locality) and type of cleft, unilateral/bilateral, complete/incomplete and site of unilateral cleft and the association between demographic factors (gender, race and locality) and LAHSHAL classification, family background and health. The $p$-value $\leq$ 0.05 was considered as significant. 


\section{RESULTS}

\section{Demographic Profile}

A total of 20 cases were seen over the period of nine years. OFC was more prevalent in female $(60 \%)$ with male representing $40 \%$ of the population. Age distribution of cases were $40 \%$ below the age of 10 years old, $40 \%$ between 11 to 20 years old and $20 \%$ of 21 years old and above. As for race, $90 \%$ OFC patients were Malay, with $5 \%$ of Chinese and Indian, respectively. Majority of patients $(75 \%)$ were from Kuantan, $10 \%$ from Kemaman and 5\% from Pekan, Kuala Terengganu and Kota Bharu, respectively (Table 1).

Table 1 Demographic profile of the OFC cases seen in IIUM

\begin{tabular}{lcc} 
Demographic profile & $\begin{array}{r}\text { Number of respondents } \\
\mathbf{N}=\mathbf{2 0}\end{array}$ & Valid percentage \\
Gender & 8 & 40 \\
Male & 12 & 60 \\
Female & & \\
Age & 8 & 40 \\
Below 10 years & 8 & 40 \\
11-20 years & 4 & 20 \\
21 years and above & & \\
Race & 18 & 90 \\
Malay & 1 & 5 \\
Chinese & 1 & 5 \\
Indian & & 5 \\
Locality & 15 & 5 \\
Kuantan & 1 & 10 \\
Pekan & 2 & 5 \\
Kemaman & 1 & 5 \\
Kuala Terengganu & 1 & \\
Kota Bahru & & \\
\hline
\end{tabular}

\section{Cleft Type}

As shown in Table 2, the most common OFC case seen was cleft lip and palate $(80 \%)$, followed by cleft palate $(15 \%)$ and facial cleft $(5 \%)$. Out of 15 cases $(75 \%)$ of unilateral cleft, $73.3 \%$ were affecting the left side compared to $26.7 \%$ right-sided cases. About $20 \%$ cases were bilateral cleft with $5 \%$ bifid uvula. Majority of cases $(70 \%)$ were complete cleft with $20 \%$ incomplete cleft.

\section{Family History and Associated Health Problems}

From the present study as shown in Table 3, $20 \%$ of patients had family history of cleft. Other health anomalies were recognised in $45 \%$ of cases (total of nine cases) including one patient being syndromic, four patients having hearing problem, two patients with speech problem, three asthmatic patients and one patient with a missing eye. Percentage of syndromic cleft case seen by this team is $5 \%$ (one case) over eight years. 
Table 2 Type of cleft cases seen in IIUM

\begin{tabular}{lcc} 
Demographic profile & $\begin{array}{c}\text { Number of respondents } \\
\boldsymbol{N}=\mathbf{2 0}\end{array}$ & Valid percentage \\
$\begin{array}{l}\text { Type of cleft } \\
\text { Cleft palate }\end{array}$ & 3 & 15 \\
Cleft lip and palate & 16 & 80 \\
Facial cleft & 1 & 5 \\
Unilateral or bilateral & 15 & 75 \\
Unilateral & 4 & 20 \\
Bilateral & 1 & 5 \\
Bifid uvula & & 30 \\
Complete or incomplete & 6 & 70 \\
Incomplete & 14 & 73.3 \\
Complete & & 26.7 \\
Side of unilateral cleft & 11 & \\
Left & 4 & \\
Right & & \\
\hline
\end{tabular}

Table 3 Family history of cleft and associated health problems

\begin{tabular}{lcc} 
Demographic & $\begin{array}{c}\text { Number of respondents } \\
\mathbf{N}=\mathbf{2 0}\end{array}$ & Valid percentage \\
Family history of cleft & 4 & 20 \\
Yes & 16 & 80 \\
No & & \\
Associated health problems & 9 & 45 \\
Yes & 11 & 55 \\
No & & \\
Syndromic & 1 & 5 \\
Yes & 19 & 95 \\
No & & \\
Health problems (9 patients) & $3 / 9$ & 30 \\
Asthmatic & $4 / 9$ & 40 \\
Hearing & $2 / 9$ & 20 \\
Speech & $1 / 9$ & 10 \\
Missing eye & & \\
\hline
\end{tabular}




\section{LAHSHAL Classification}

The areas involved in the cleft are denoted by the specific alphabet standing for it with capital letter indicating complete cleft and small letter representing incomplete cleft.
Based on LAHSHAL classification (Kriens, 1989), $15 \%$ of our OFC cases were complete left cleft alveolus, lip and hard palate and another $15 \%$ were complete right cleft lip, alveolus, hard and soft palate. Detail and percentage of cases are presented in Table 4 .

Table 4 LAHSHAL classification

\begin{tabular}{|c|c|c|c|}
\hline LAHSHAL & Frequency & Percentage & Analysis \\
\hline$----H A L$ & 3 & 15.0 & Complete left cleft alveolus, lip and hard palate \\
\hline LAHS-- & 3 & 15.0 & Complete right cleft lip, alveolus, hard and soft palate \\
\hline LAH-HAL & 2 & 10.0 & Complete bilateral cleft lip, alveolus and hard palate \\
\hline$---S H A L$ & 2 & 10.0 & $\begin{array}{l}\text { Complete cleft soft palate with left cleft of hard palate, } \\
\text { alveolus and lip }\end{array}$ \\
\hline$-----a-$ & 1 & 5.0 & Incomplete left cleft alveolus \\
\hline -----AL & 1 & 5.0 & Complete left cleft alveolus and lip \\
\hline ----hat & 1 & 5.0 & $\begin{array}{l}\text { Incomplete left cleft hard palate and alveolus and } \\
\text { complete left cleft lip }\end{array}$ \\
\hline ----hal & 1 & 5.0 & Incomplete left cleft hard palate, alveolus and lip \\
\hline ---S--- & 1 & 5.0 & Complete cleft soft palate \\
\hline$--\mathrm{HSHAL}$ & 1 & 5.0 & $\begin{array}{l}\text { Complete right cleft of hard palate, complete cleft of soft } \\
\text { palate, with complete left cleft hard palate, alveolus and lip }\end{array}$ \\
\hline -ah-hal & 1 & 5.0 & $\begin{array}{l}\text { Incomplete right cleft alveolus and hard palate with } \\
\text { incomplete left cleft of hard palate, alveolus and lip }\end{array}$ \\
\hline$-\mathrm{AH}-\mathrm{HA}-$ & 1 & 5.0 & Complete bilateral cleft alveolus and hard palate \\
\hline LAH---- & 1 & 5.0 & Complete right cleft lip, alveolus and hard palate \\
\hline
\end{tabular}

\section{Correlations between Gender, Race, Locality with Type of Cleft}

There was no significant relationship between demographic factors (gender, race and locality) with type of cleft as presented in Table 5.

\section{Correlations between Gender, Race, Locality with LAHSHAL, Family History and Associated Health Problems}

There was no significant relationship between demographic factors (gender, race and locality) with LAHSHAL, family background and associated health (Table 6). 
Table 5 Correlations between gender, race and locality with type of cleft

\begin{tabular}{|c|c|c|c|c|c|c|c|c|}
\hline Variable & & Gender & Race & Locality & $\begin{array}{l}\text { Type of } \\
\text { cleft }\end{array}$ & $\begin{array}{c}\text { Unilateral or } \\
\text { bilateral }\end{array}$ & $\begin{array}{l}\text { Complete or } \\
\text { incomplete }\end{array}$ & $\begin{array}{c}\text { Side of } \\
\text { unilateral } \\
\text { cleft }\end{array}$ \\
\hline \multirow[t]{2}{*}{ Gender } & $\begin{array}{l}\text { Pearson } \\
\text { correlation }\end{array}$ & 1 & -.171 & .247 & .047 & .257 & .356 & -.328 \\
\hline & Sig. (2-tailed) & - & .471 & .294 & .845 & .274 & .123 & .158 \\
\hline \multirow[t]{2}{*}{ Race } & $\begin{array}{l}\text { Pearson } \\
\text { correlation }\end{array}$ & -.171 & 1 & -.163 & -.168 & .121 & -.252 & -.211 \\
\hline & Sig. (2-tailed) & .471 & - & .492 & .478 & .612 & .285 & .373 \\
\hline \multirow[t]{2}{*}{ Locality } & $\begin{array}{l}\text { Pearson } \\
\text { correlation }\end{array}$ & .247 & -.163 & 1 & .119 & -.072 & .339 & -.104 \\
\hline & Sig. (2-tailed) & .294 & .492 & - & .618 & .761 & .143 & .662 \\
\hline \multirow[t]{2}{*}{ Type of cleft } & $\begin{array}{l}\text { Pearson } \\
\text { correlation }\end{array}$ & .047 & -.168 & .119 & 1 & .072 & .100 & .092 \\
\hline & Sig. (2-tailed) & .845 & .478 & .618 & - & .762 & .674 & 699 \\
\hline \multirow[t]{2}{*}{$\begin{array}{l}\text { Unilateral or } \\
\text { bilateral }\end{array}$} & $\begin{array}{l}\text { Pearson } \\
\text { correlation }\end{array}$ & .257 & .121 & -.072 & .072 & 1 & .206 & -.547 \\
\hline & Sig. (2-tailed) & .274 & .612 & .761 & .762 & - & .384 & .013 \\
\hline \multirow[t]{2}{*}{$\begin{array}{l}\text { Complete or } \\
\text { incomplete }\end{array}$} & $\begin{array}{l}\text { Pearson } \\
\text { correlation }\end{array}$ & .356 & -.252 & .339 & .100 & .206 & 1 & -.526 \\
\hline & Sig. (2-tailed) & .123 & .285 & .143 & .674 & .384 & - & .017 \\
\hline \multirow{2}{*}{$\begin{array}{l}\text { Side of } \\
\text { unilateral } \\
\text { cleft }\end{array}$} & $\begin{array}{l}\text { Pearson } \\
\text { correlation }\end{array}$ & -.328 & -.211 & -.104 & .092 & -.547 & -.526 & 1 \\
\hline & Sig. (2-tailed) & .158 & .373 & .662 & 699 & .013 & .017 & - \\
\hline
\end{tabular}

Note: Correlation is significant at the 0.05 level (2-tailed); Number of respondents $=20$. 
Table 6 Correlations between gender, race, locality with LAHSHAL, family history and associated health problems

\begin{tabular}{llcccccc}
\hline \multirow{2}{*}{ Gender } & Variable & Gender & Race & Locality & LAHSHAL & Family & Health \\
& Pearson correlation & 1 & -.171 & .247 & .034 & .153 & -.082 \\
\multirow{2}{*}{ Race } & Sig. (2-tailed) & - & .471 & .294 & .886 & .519 & .731 \\
& Pearson correlation & -.171 & 1 & -.163 & -.079 & -.157 & -.074 \\
& Sig. (2-tailed) & .471 & - & .492 & .741 & .508 & .757 \\
Locality & Pearson correlation & .247 & -.163 & 1 & .159 & .281 & -.035 \\
& Sig. (2-tailed) & .294 & .492 & - & .504 & .231 & .884 \\
\multirow{2}{*}{ LAHSHAL } & Pearson correlation & .034 & -.079 & .159 & 1 & .143 & .325 \\
& Sig. (2-tailed) & .886 & .741 & .504 & - & .547 & .162 \\
\multirow{2}{*}{ Family } & Pearson correlation & .153 & -.157 & .281 & .143 & 1 & .050 \\
& Sig. (2-tailed) & .519 & .508 & .231 & .547 & - & .833 \\
Health & Pearson correlation & -.082 & -.074 & -.035 & .325 & .050 & 1 \\
& Sig. (2-tailed) & .731 & .757 & .884 & .162 & .833 & - \\
\hline
\end{tabular}

Note: Correlation is significant at the 0.05 level (2-tailed); Number of respondents $=20$.

\section{Treatment}

\section{a) Multicentre}

All OFC patients seen in IIUM have had or are having treatment elsewhere for different procedures at different point in life (Table 7). None receives comprehensive treatment from one centre only. This emphasise the need of establishing one centre that is reliable to provide all necessary treatment for cleft especially in Kuantan, Pahang. Currently, 15 out of 20 patients $(75 \%)$ are having some form of treatment in IIUM. b) Treatment received

All cases involving cleft lip underwent lip repair with one $(5 \%)$ underwent secondary lip repair. Thirteen patients (65\%) underwent palatoplasty and five out of them $(38.5 \%)$ have to undergo secondary palatoplasty due to fistula. Four had alveolar bone graft (ABG) done and $75 \%$ of that have to repeat the surgery. Thirty percent had undergone orthodontics treatment including the rapid-maxillary expansion (RME). The rest of the treatment and its percentage are presented in Table 8. 
Table 7 Centres of prior treatment received

\begin{tabular}{|c|c|c|c|}
\hline Centres & Treatment received & Frequency of patients & $\%$ of patients \\
\hline Hospital Pantai, Kuala Lumpur & Lip and palate repair & $3 / 20$ & 12 \\
\hline KPJ Kuantan & $\begin{array}{l}\text { Lip and palate repair } \\
\text { Grommet insertion }\end{array}$ & $3 / 20$ & 12 \\
\hline University Malaya Medical Centre & $\begin{array}{l}\text { Lip and palate repair } \\
\text { Facial cleft repair }\end{array}$ & $3 / 20$ & 12 \\
\hline US Mercy NAVY Ship & Palate repair, $A B G$ & $2 / 20$ & 8 \\
\hline HUSM Kubang Kerian & Lip and palate repair & $2 / 20$ & 8 \\
\hline Hospital Ampang Puteri & Lip and palate repair & $2 / 20$ & 8 \\
\hline Hospital Kuala Lumpur & $\begin{array}{l}\text { Lip and palate repair } \\
\text { Tongue surgery }\end{array}$ & $2 / 20$ & 8 \\
\hline KPJ Kelantan & Lip and palate repair & $1 / 20$ & 4 \\
\hline Subang Jaya Medical Centre & Lip and palate repair & $1 / 20$ & 4 \\
\hline Hospital Seberang Prai, Penang & Lip and palate repair & $1 / 20$ & 4 \\
\hline Hospital Pantai Ipoh & Lip and palate repair & $1 / 20$ & 4 \\
\hline Hospital Sultan Haji Ahmad Shah & Palate repair & $1 / 20$ & 4 \\
\hline Hospital PUSRAWI & Lip and palate repair & $1 / 20$ & 4 \\
\hline Kem Tentera Batu 10 & Orthodontics & $1 / 20$ & 4 \\
\hline Klinik Pergigian Ortodontik Cahaya Suria & Orthodontics & $1 / 20$ & 4 \\
\hline
\end{tabular}

Note: All the name of the hospitals are based on the referral letter.

Table 8 Treatment received by OFC patients

\begin{tabular}{|c|c|c|}
\hline Treatment received & Frequency & Percentage \\
\hline Lip repair & $16 / 16$ & 100 \\
\hline Secondary lip repair/lip revision & $1 / 20$ & 5 \\
\hline Palatoplasty & $13 / 20$ & 65 \\
\hline Secondary palatoplasty (due to failure or fistula) & $5 / 13$ & 38.5 \\
\hline$A B G$ & $4 / 20$ & 20 \\
\hline Repeat ABG (Due to failure/inadequate bone) & $3 / 4$ & 75 \\
\hline Planning for $A B G$ & $5 / 20$ & 25 \\
\hline Orthodontics & $6 / 20$ & 30 \\
\hline Planning for orthodontics & $2 / 20$ & 10 \\
\hline Grommet insertion & $2 / 20$ & 10 \\
\hline Facial cleft repair & $1 / 20$ & 5 \\
\hline Tongue surgery & $1 / 20$ & 5 \\
\hline Uvulaplasty & $1 / 20$ & 5 \\
\hline Paediatric dentistry treatment & $5 / 20$ & 25 \\
\hline Speech therapy & $5 / 20$ & 25 \\
\hline Psychology & $10 / 20$ & 50 \\
\hline
\end{tabular}




\section{Prevalence}

Cleft lip and palate rate in Malaysia were reported to be one out of 941 births (Oral Health Division, Ministry of Health Malaysia, 1998). The Pahang population in 2016 was estimated to be 1.63 million with crude birth rate of 17/1,000 (Department of Statistics Malaysia, 2019). Hence, the total birth for the year 2016 was estimated to be 27,710 . Therefore, new cleft lip and palate cases was estimated to be around 29 cases $(29.4 \%)$ per year in the state of Pahang. For nine years, with the total of 20 cases seen, it could be hypothesised that IIUM-MDCT had seen only around $7.6 \%$ of the possible total OFC cases in Pahang.

\section{DISCUSSION}

Majority of the patients were female which comprised $60 \%$ of the patients compared to male patients which was $40 \%$. It coincided with a previous study that found female were more affected than males (Ali Shah et al., 2015). Majority of the patients presented with cleft were Malay (90\%) followed by Chinese and Indian, both at $5 \%$. The Malay predilection reflect the higher Malay population living in Kuantan (Department of Statistics Malaysia, 2011).

From the present study, out of the 20 patients, $80 \%$ were having cleft lip and palate, $15 \%$ were having cleft palate, $5 \%$ were having facial cleft while none of cleft lip was reported. This pattern is similar to another study conducted in University of Malaya, whereby out of the 526 children with oral cleft, $77.8 \%$ were cleft lip and palate, $13.5 \%$ were cleft palate, and $8.7 \%$ cleft lip (Ali Shah et al., 2015).

Family history with clefts was found $20 \%$ from the total patients of the present study. Study conducted by Jaruratanasirikul et al. (2008) had shown slightly lower finding at $17.7 \%$. For non-syndromic cleft, it was initially thought that hereditary played significant role (Hupp et al., 2013). However, studies have been able to implicate genetics in only $20 \%$ to $30 \%$ of patients with cleft lip or palate (Hupp et al., 2013).

The reported incidence of cleft patients associated with health issues was $45 \%$ in the present study, which was similarly reported previously, whereby out of the 460 cleft infants born, $36.7 \%$ had associated malformations (Stoll et al., 2000).

In terms of surgical management, all patients with cleft lip, in the present study had undergone surgical lip repair. This perhaps due to the concern of most parents about their children appearances. Out of these patients, small percentage (5\%) had undergone secondary lip revision. Secondary lip revision can be indicated in whistle deformity, a poorly defined philtrum, notching of the upper lip, bulging on the lateral lip segment and volume deficiency at the upper vermilion (Nadjmi et al., 2016).

The present study found that $38.5 \%$ of patients have to undergo secondary palatoplasty, which is often needed due to the failure of the primary palate repair that potentially produced fistula. Another surgical treatment that was found to have high redo rate $(75 \%)$ is $\mathrm{ABG}$ which is integral to the surgical management of cleft lip/palate patients. Other study stated $85 \%$ success rate of ABG (Revington et al., 2010). With this percentage of failure, focus should be given to revamp the overall approach to $\mathrm{ABG}$ (on both clinician and patient aspects) and to enhance the clinical skill to further improve the outcome of ABG of this centre. ABG can obliterate an oronasal fistula, stabilise the dental arch and offer bone matrix for adjacent dental eruption. Conversely, an unrepaired alveolar bone defect can lead to instability and increasing medial collapse of the dental arch, persistent fistula and abnormal dental eruption either side of the defect. In the present study, $20 \%$ of the patients had underwent ABG, while 25\% were in planning stage to do $A B G$ in future.

In the present study, $95 \%$ of the patients received multi-centred treatment including 
from IIUM Kuantan, KPJ Kuantan, Hospital Ampang Puteri, KPJ Kelantan, Hospital Pantai Ipoh, Hospital Sultan Haji Ahmad Shah, University Malaya Medical Centre, Hospital PUSRAWI, Subang Jaya Medical Centre, Hospital Seberang Prai and Hospital Pantai Kuala Lumpur. It proved the necessity of establishing a comprehensive cleft centre that can provide the best treatment for cleft patients throughout their life, especially for the people of Pahang.

From the present study, only approximately $7.6 \%$ of potential cleft cases were treated in the state of Pahang. Therefore, future plan should be focused on the promotion of the service to the people of Pahang, especially, and the east coast of peninsular Malaysia, generally. Since there is a comprehensive team in IIUM-MDCT, which includes the orthodontists, plastic surgeons, maxillofacial surgeons, paediatric dentists, psychologists, speech therapists and otorhinolaryngologists, it would be very beneficial for patients from Pahang, logistically to have treatment here, rather in farther place such as the Klang Valley.

The limitation of the present study was the secondary data that was used. Patients' information was extracted from their medical records or folders available at the clinic in the Kulliyyah of Dentistry, IIUM Kuantan. Cleft cases in IIUM had been seen and handled individually prior to the establishment of the IIUM-MDCT in 2016. Therefore, some records were not in Kulliyyah of Dentistry and some information were missing. Some of the information were not clearly stated, hence additional appointments including phone calls to patients or guardian were necessary to further confirm the information. Since the establishment, all patients were called back and seen jointly in the IIUMMDCT for proper assessment, treatment planning and records. This is to ensure coherent patients' management and proper data on the IIUM-MDCT registry.

\section{CONCLUSION}

This centre had seen a total of 20 cases, approximately $7.6 \%$ of the potential OFC cases in Pahang with only one syndromic patient seen up to October 2018. Females have higher cleft prevalence compared to males, unilateral cleft was found more common to happen, compared to bilateral. There was no significant relationship between demographic factors (gender, race and locality) with type of cleft, unilateral/ bilateral, complete/incomplete and site of unilateral cleft, LAHSHAL classification, family background and health.

\section{ACKNOWLEDGEMENTS}

Appreciation goes to all IIUM-MDCT members, patients and family members who were involved in the present study.

\section{REFERENCES}

Ali Shah SY, Abdul Rahman ZA, Mirani SA, Shaikh MI, Khattak MN, Sahito MA (2015). Demographic data on the characterization of oral clefts in Malaysia. Pak Oral Dent F, 35(1): 108-110.

Boo NY, Arshad AR (1990). A study of cleft lip and palate in neonates born in a large Malaysian maternity hospital over a 2-year period. Singapore Med F, 31(1): 59-62.

Department of Statistics Malaysia (2011). Population Distribution by Local Authority Areas and Mukims 2010. Putrajaya: Department of Statistics Malaysia, p. 81.

Department of Statistics Malaysia (2019). Malaysia@a Glance,Pahang. Retrieved 17 September 2019, from https://www. dosm.gov.my/v1/index.php?r=column/ cone\&menu_id=b21JM0IwRGdGSjVn V1dOZktWVGYzdz09 
Dvivedi J, Dvivedi S (2012). A clinical and demographic profile of the cleft lip and palate in Sub-Himalayan India: A hospitalbased study. Indian $\mathcal{F}$ Plast Surg, 45(1): 115-120.

Fraser FC (1976). The multifactorial/threshold concept: Uses and misuses. Teratology, 14(3): 267-280. https://doi.org/10.1002/ tera. 1420140302

Hupp JR, Ellis E III, Tucker MR (2013). Contemporary Oral and Maxillofacial Surgery, 6th edn. St. Louis: Elsevier Mosby, pp. 585-615.

Jaruratanasirikul S, Chichareon V, Pattanapreechawong N, Sangsupavanich P (2008). Cleft lip and/or palate: 10 years experience at a pediatric cleft center in Southern Thailand. Cleft Palate Craniofac F, 45(6): 597-602. https://doi.org/10.1597/07176.1

Källén B (2003). Maternal drug use and infant cleft lip/palate with special reference to corticoids. Cleft Palate Craniofac F, 40(6): 624-628. https://doi.org/10.1597/02-077

Källén K (1997). Maternal smoking and orofacial clefts. Cleft Palate Craniofac $\mathcal{F}, 34(1)$ : 11-16. https://doi.org/10.1597/15451569_1997_034_0011_msaoc_2.3.co_2

Kriens O (1989). Lahshal: A concise documentation system for cleft lip, alvolus and palate diagnoses. In: Kriens O (ed.), What is Cleft Lip and Palate? A Multidisciplinary Update - Proceedings of an Advanced Workshop, Bremen 1987. Stuttgart: Thieme Publishing Group.

LaRossa D (1997). Cleft lip and palate. In: Schwartz MW, Curry TA, Sargent AJ, Blum NJ, Fein JA (eds.), Pediatric Primary Care: A Problem-Oriented Approach, 3rd edn. Maryland Heights: Mosby, pp. 833834.
Oral Health Division, Ministry of Health Malaysia (1998). National Oral Health Survey of Schoolchildren 1997 (NOHSS '97). Putrajaya: Oral Health Division, Ministry of Health Malaysia.

Nadjmi N, Amadori S, Van de Casteele E (2016). Secondary cleft lip reconstruction and the use of pedicled, deepithelialized scar tissue. Plast Reconstr Surg Glob Open, 4(10): e1061. https://doi.org/10.1097/ gox.0000000000001061

Revington PJ, McNamara C, Mukarram S, Perera E, Shah HV, Deacon SA (2010). Alveolar bone grafting: Results of a national outcome study. Ann $R$ Coll Surg Engl, 92(8): 643-646. https://doi.org/10.1308/00 3588410X12699663904790

Stoll C, Alembik Y, Dott B, Roth MP (2000). Associated malformations in cases with oral clefts. Cleft Palate Craniofac F, 37(1): 41-47. https://doi.org/10.1597/15451569_2000_037_0041_amicwo_2.3.co_2

Thong MK, Ho JJ, Khatijah NN (2005). A population-based study of birth defects in Malaysia. Ann Hum Biol, 32(2): 180-187. https://doi. org/10.1080/03014460500075332

Vanderas AP (1987). Incidence of cleft lip, cleft palate, and cleft lip and palate among races: A review. Cleft Palate F, 24(3): 216-225.

Yi NN, Yeow VK, Lee ST (1999). Epidemiology of cleft lip and palate in Singapore: A 10year hospital-based study. Ann Acad Med Singap, 28(5): 655-659. 